\title{
KAJIAN LITERATUR: HUBUNGAN ANTARA TINGKAT \\ PENGETAHUAN TANDA AWAL GEJALA STROKE DENGAN \\ KEPUTUSAN MENCARI BANTUAN KESEHATAN PADA INDIVIDU \\ DENGAN RISIKO STROKE
}

\author{
Desna Ria Simatupang ${ }^{1}$, Dora Samaria ${ }^{2}$ \\ ${ }^{1}$ Siloam Hospital Purwakarta, Jawa Barat \\ ${ }^{2}$ Program S1 Keperawatan, Fakultas Ilmu Kesehatan UPN Veteran Jakarta \\ Email: dora.samaria@upnvj.ac.id
}

\begin{abstract}
ABSTRAK
Stroke merupakan gangguan pada pembuluh darah dimana terdapat adanya gumpalan atau sumbatan yang mengakibatkan aliran darah mengalami gangguan untuk mengalir ke otak. Stroke menduduki peringkat pertama sebagai penyakit mematikan yang tidak menular. Tujuan dilakukannya kajian literatur adalah untuk menganalisis hubungan antara pengetahuan tanda gejala awal stroke dengan keputusan mencari bantuan kesehatan pada individu dengan risiko stroke. Pengumpulan data dengan menggunakan metode Systematic Literature Review. Hasil analisis menunjukkan bahwa tingkat pengetahuan termasuk dalam kategori rendah, dan kesadaran individu akan tanda gejala awal stroke juga termasuk dalam kategori rendah. Individu akan mencari bantuan kesehatan seperti menghubungi ambulance, dokter, dan pergi ke rumah sakit, meskipun memiliki tingkat pengetahuan dan kesadaran yang rendah terhadap tanda gejala awal stroke. Hasil kajian literatur ini menunjukkan bahwa tingkat pengetahuan dan kesadaran yang rendah terhadap tanda gejala stroke tidak ada kaitannya terhadap perilaku seseorang untuk menghubungi petugas kesehatan. Oleh karena itu, peneliti menyimpulkan tidak ada hubungan antara tingkat pengetahuan tanda gejala awal stroke terhadap keputusan mencari bantuan kesehatan pada individu dengan risiko stroke.
\end{abstract}

Kata kunci:, pengetahuan tanda awal gejala stroke, perilaku mencari bantuan kesehatan, stroke

\section{ABSTRACT}

Stroke is a vascular disorder in which there is a clot or blockage that results in impaired blood flow to flow to the brain. Ranked first cause of death was a stroke of all ages, with a percentage of $15.4 \%$ and was ranked first stroke deadly disease that is not contagious. The purpose of the literature review is to analyze the relationship between knowledge signs early symptoms of stroke with the decision to seek help health in individuals with stroke risk. Data collection using the Systematic Literature Review. The results have been analyzed that the level of knowledge in the category of low, and individual consciousness will mark the start of stroke symptoms also included in the low category. They will seek medical assistance such as calling an ambulance, a doctor, and went to the hospital, even though they have a level of knowledge and awareness were less likely to mark the start of stroke symptoms. The results of the study of literature that the level of knowledge and low awareness of the signs of stroke symptoms not related to the behavior of a person to contact health care providers. Therefore, researchers concluded there was no correlation between the level of knowledge of the early symptoms of stroke signs to the decision to seek help health in individuals with stroke risk.

Keywords: knowledge of initial stroke signs, health seeking behaviour, stroke

Alamat korespondensi: Email: dora.samaria@upnvj.ac.id

Nomor Hp: 085219044214 


\section{PENDAHULUAN}

Stroke disebabkan oleh gangguan suplai darah ke otak, yang dapat diakibatkan oleh penggumpalan atau penyumbatan aliran pembuluh darah sehingga mengakibatkan pasokan oksigen dan nutrisi mengalami penurunan dan menyebabkan kerusakan pada jaringan otak (World Health Organization, 2016). Stroke adalah penyebab kematian kedua bagi orang-orang di atas usia 60 tahun dan penyebab utama kelima pada orang berusia 15 sampai 59 tahun. Setiap tahun, hampir enam juta orang di seluruh dunia meninggal karena stroke. Satu dari enam orang di seluruh dunia akan mengalami stroke dalam hidup mereka. Setiap enam detik, stroke dapat membunuh seseorang (World Stroke Organization, 2012).

Data Departemen Kesehatan Tahun 2008 menunjukkan bahwa prevalensi kasus stroke di Indonesia sebesar 8.3 per 1000 penduduk. Stroke juga merupakan peringkat pertama penyebab kematian semua umur, dengan persentase $15.4 \%$ dan stroke juga menduduki peringkat pertama diantara penyakit mematikan yang tidak menular. Jumlah penderita stroke di Indonesia diperkirakan 500.000 setiap tahun dan sekitar $2.5 \%$ atau 250.000 orang meninggal dunia, sisanya cacat ringan atau berat (Departemen Kesehatan Republik Indonesia, 2008)

Efek dari stroke tergantung pada bagian mana dari otak mengalami kerusakan dan seberapa parah hal itu dipengaruhi, maka dari itu stroke yang sangat parah dapat menyebabkan kematian mendadak. Permasalahan yang muncul pada tingginya angka kejadian stroke di dunia adalah kurangnya kesadaran terhadap faktor risiko stroke, kurangnya pengetahuan mengenai tanda dan gejala stroke, belum optimalnya pelayanan stroke, dan rendahnya ketaatan terhadap program terapi untuk pencegahan stroke berulang (Zulfa R, 2012).

Tanda dan gejala yang paling umum dari stroke adalah kelemahan mendadak atau mati rasa pada wajah, lengan atau kaki, paling sering pada satu sisi tubuh. Gejala lain termasuk: kebingungan, kesulitan berbicara atau memahami pembicaraan; kesulitan melihat dengan satu atau kedua mata; kesulitan berjalan, pusing, kehilangan keseimbangan atau koordinasi; sakit kepala parah tanpa diketahui penyebabnya; pingsan atau tidak sadarkan diri (World Health Organization, 2016). Oleh karena itu masyarakat perlu mengetahui cara pencegahan pada stroke dan tanda gejala awal pada stroke.

Salah satu kunci keberhasilan penanganan kasus stroke terletak pada pengenalan secara dini gejala awal stroke, idealnya gejala awal stroke diketahui oleh pasien, orang-orang di sekitarnya atau keluarga sehingga mengupayakan pertolongan medis. Hal kunci kedua adalah kemampuan praktisi medis untuk mendiagnosis, melakukan pemeriksaan, dan memberikan tata laksana yang cepat dan tepat, penanganan pada pasien stroke maksimal 6 jam setelah mengalami onset namun prinsip yang harus diingat adalah semakin cepat, semakin minimal kerusakan sela otak yang terjadi (Wahjoepramono, 2010)

Hasil penelitian Zulfa, R. (2012) menunjukan bahwa dari 85 responden yang diteliti, indivdu yang memiliki risiko stroke tinggi sebanyak 12 orang $(14,1 \%)$, responden dengan pengetahuan mengenai tanda gejala awal stroke yang baik sebanyak 13 orang $(15,3 \%)$. Penelitian ini juga menunjukan bahwa ada hubungan antara individu yang memiliki tingkat risiko stroke dengan pengetahuan tentang stroke yang dikatagorikan sedang dengan jumlah 65 responden yakni $(\mathrm{p}=0,017)$ 
dari 85 responden, dan individu yang memiliki faktor risiko stroke yang tinggi mempunyai 5,8 kali pengetahuan tentang stroke yang lebih baik $(\mathrm{OR}=5,80$; 95\% CI=1,486-22,668).

Peningkatan pengetahuan individu terhadap deteksi dini stroke bertujuan agar individu yang produktif khususnya yang memiliki risiko tinggi terhadap stroke dapat diselamatkan dari serangan stroke. Sekitar $85 \%$ dari mereka yang mempunyai faktor risiko stroke dapat dicegah jika diidentifikasi (European Society Of Cardiology, 2012). Deteksi dan identifikasi dini dilakukan sebagai upaya awal untuk seseorang kemudian dapat mengambil keputusan mencari bantuan kesehatan sesegera mungkin untuk mencegah terjadinya perburukan gejala stroke. Berdasarkan hal tersebut, perlu dilakukan studi lebih lanjut tentang hubungan pengetahuan tanda gejala awal stroke dengan keputusan mencari bantuan kesehatan pada individu dengan risiko stroke.

\section{METODE PENELITIAN}

Penelitian ini menggunakan systematic literature review yakni model kajian literatur yang menggunakan penelitian murni dimana peneliti meninjau data primer yang dapat bersifat data kualitatif atau kuantitatif mengenai topik tertentu (Moule dan Goodman, 2009). Tahapan pencarian literatur yang dilakukan yaitu, memahami pertanyaan penelitian, tujuan penelitian, dan yang dibutuhkan peneliti untuk memfokuskan artikel penelitian salah satunya dengan batasan-batasan yang diteliti seperti kriteria inklusi dan eksklusi untuk memfokuskan artikel penelitian. Setelah itu menentukan kata kunci atau dapat juga menggunakan sinonim dari kata kunci tersebut yang akan digunakan dalam melakukan pencarian sehingga memudahkan peneliti dalam melakukan kajian literatur (Aromataris, E., Riitano, 2014)

Selanjutnya peneliti melihat referensi yang ada pada artikel penelitian untuk membuktikan keakuratannya, diakhiri dengan finding experts yakni, menghubungi penulis untuk memperjelas rincian studi sehingga kajian literatur mendapatkan studi yang relevan dan akurat. Peneliti melakukan kajian literatur secara komperhensif berdasarkan kerangka konsep (Gambar 1).

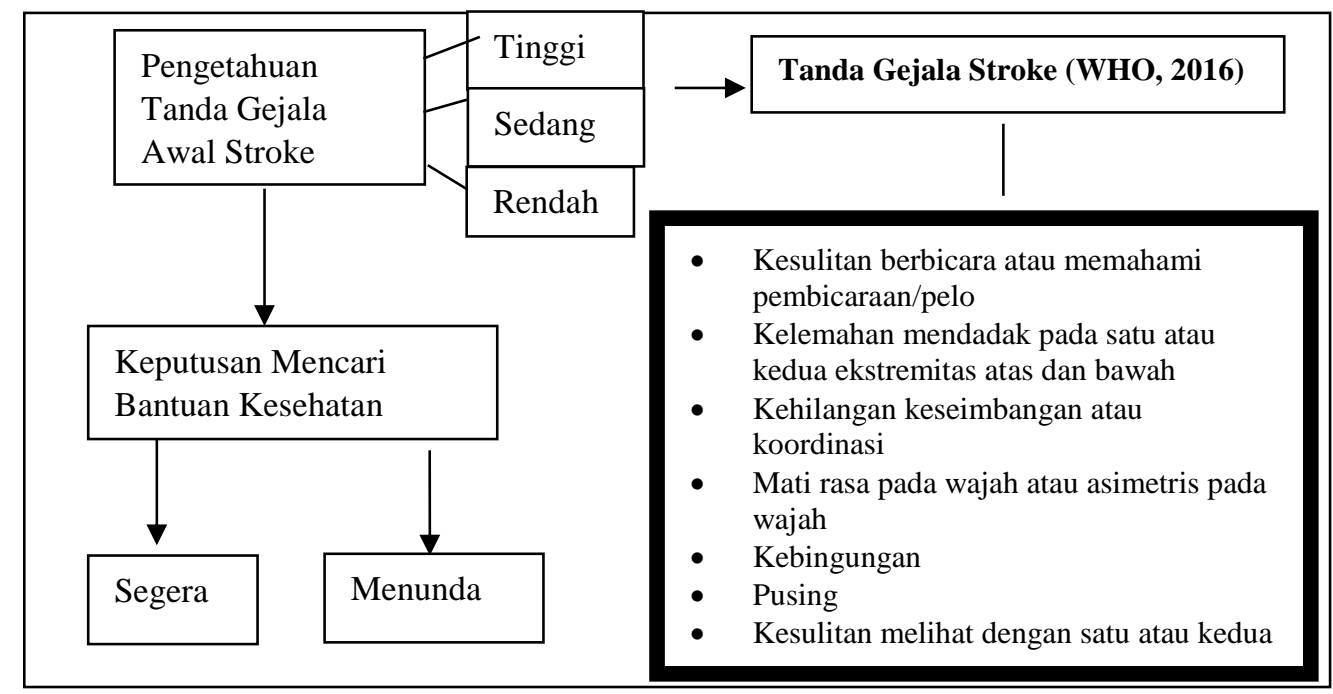

Gambar 1. Kerangka Konsep 
Kriteria inklusi dalam kajian literatur ini meliputi artikel yang menggunakan bahasa Indonesia dan bahasa Inggris, dipublikasikan dari tahun 2006-2016, tersedia dalam full text, bersifat penelitian murni dengan desain kuantitatif, karakteristik responden berusia 15-80 tahun yang belum pernah terkena stroke namun diindikasi memiliki risiko stroke setelah dikaji (suspect stroke), serta artikel yang membahas mengenai stroke atau keputusan mencari bantuan kesehatan terhadap stroke. Kriteria eksklusi kajian literatur ini yaitu individu yang terkena secondary stroke. Kata kunci yang digunakan meliputi fast stroke, sign and symptoms, risk stroke, fast stroke campaign, knowledge of fast stroke, fast campaign, pre-hospital of risk stroke. Peneliti juga menggunakan boolean operators seperti AND, OR, NOT, or AND NOT. Database yang digunakan yakni EBSCO, PubMed, Springer Link, Infotrac Health And Medical Collection (GALE), dan Hand Searching. Peneliti mempertimbangkan aspek etik didalam penelitian yaitu meliputi menghindari plagiarisme, menghindari duplikasi publikasi, menjaga transparansi, serta menjaga keakuratan dalam pencarian artikel (Wager \&w Wiffen, 2011).

Kajian literatur ini merupakan systematic literature review dengan menggunakan JBI Critical Appraisal Checklist Fof Descriptive/ Case Series untuk menyaring artikel yang ditemukan. Artikel yang terkumpul dianalisis dengan menggunakan metode Simplified Approach yang merupakan bagian dari Thematic Analysis. Menurut Aveyard (2014) pendekatan tematik adalah menyimpulkan literatur yang relevan untuk mereka yang baru memulai melakukan literatur review. Metode ini disederhanakan dan disesuaikan dengan ide ide yang dihasilkan dari karya peneliti handal yang telah meneliti analisis dan sintesis sastra secara terperinci. Tahapan analisis tersebut meliputi menyediakan ringkasan kritis, identifikasi tema, mengembangkan tema, mendiskusikan kekuatan dari bukti, penamaan tema, membandingkan tema, dan bekerja dengan tema yang tidak saling mendukung.

\section{HASIL PENELITIAN DAN PEMBAHASAN}

Total keseluruhan data base dan kata kunci yang digunakan peneliti didapatkan 1725 artikel. Sebanyak 1718 artikel dieksklusi sehingga literature yang sesuai dengan kriteria inklusi sebanyak 7 artikel, kemudian dilakukan critical appraisal. Prisma Flow Diagram (Gambar 2) menjelaskan tentang fase pencarian literatur yang dilakukan.

Peneliti telah menemukan tujuh artikel yang sesuai dengan kriteria inklusi, setelah itu peneliti melakukan ringkasan artikel. Peneliti telah merangkum isi dari ketujuh artikel yang sesuai dengan kriteria inklusi. Tujuh artikel tersebut membahas mengenai seberapa jauh pengetahuan individu yang memiliki risiko stroke terhadap tanda gejala stroke, dan bagaimana perilaku individu terhadap keputusan mereka untuk mencari bantuan kesehatan baik meresponinya dengan pergi kerumah sakit atau menelepon ambulance. Hal ini dapat diketahui dalam artikel yang ditulis oleh Bietzk, E., et al. (2012), Hickey, A., et al. (2012), Lakshmi, K., et al. (2014), Anuar, D, MK., et al.(2014), Hickey, A., et al. (2009), Wahab, K. W., et al. (2008), Zulfa, R. (2012). 


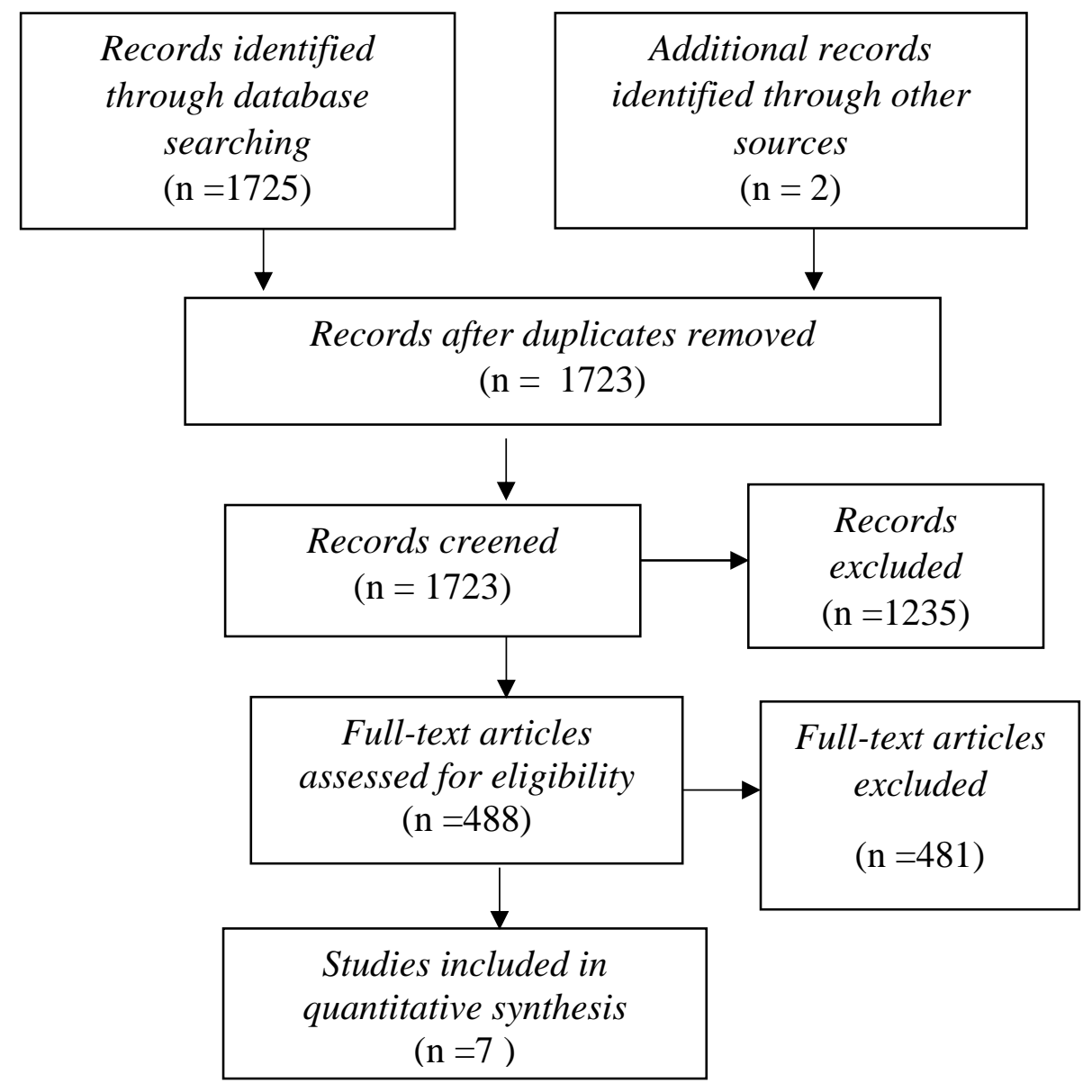

Gambar 2. Prisma Flow Diagram

Artikel yang membahas mengenai tingkat pengetahuan individu yang memiliki risiko stroke ditulis oleh Bietzk, E.,et al. (2012), Wahab, K. W.,et al. (2008), Hickey, A.,et al. (2009), Anuar, D, MK.,et al.(2014), Lakshmi, K.,et al. (2014), Hickey, A.,et al. (2012), dan Zulfa, R. (2012). Penulis menemukan tujuh artikel ini dengan membahas pengetahuan individu yang memiliki risko stroke terhadap tanda gejala stroke seperti berbicara tidak jelas, kelemahan pada lengan atau kaki atau satu sisi tubuh, sakit kepala berat, gangguan penglihatan, kesulitan dalam pemahaman mendadak atau kebingungan, pelo, perubahan sensorik tubuh, wajah asimetris, kehilangan keseimbangan atau koordinasi.

Keseluruhan artikel yang membahas pengetahuan terhadap gejala stroke, dikaitkan dengan individu dapat mengingat atau menyebutkan kembali tanda gejala stroke secara berulang. Beberapa artikel juga membahas individu tidak dapat mengingat atau menyebutkan kembali tanda gejala stroke. Peneliti menggolongkan hasil tingkat pengetahuan bedasarkan tinggi, sedang, rendah berdasarkan hasil akhir dari setiap artikel.

Peneliti menemukan lima dari tujuh artikel bukan hanya membahas pengetahuan individu terhadap tanda gejala stroke namun reaksi mereka ketika stroke meyerang, artike tersebut dibahas oleh Bietzk, E., et all. (2012), Anuar, D, MK., et all.(2014), Lakshmi, K., et all. (2014), Hickey, A., et all. (2012), Zulfa, R. (2012). Artikel ini membahas Health Seeking Behavior. Bagaimana kesadaran dan respon individu yang memiliki risiko stroke terhadap stroke yang dapat menyerang mereka. Respon tersebut dapat dijelaskan seperti pergi ke rumah sakit ketika stroke menyerang,tidak memilki aksi,tidak peduli dan membiarkan, menghubungi petugas kesehatan atau ambulance. 
Peneliti melakukan analisis data dengan menggunakan Simplified Approach yang merupakan bagian dari Thematic Analysis. Peneliti menunjukan hasil dari beberapa artikel yang telah di kategorikan bedasarkan tema yang didapat, tema tersebut dapat dilihat pada Tabel 1. Dalam analisis ini peneliti menunjukan tema "Knowledge Of Stroke" dengan "Health Seeking Behavior”.

Tabel 1. Analisis Tematik

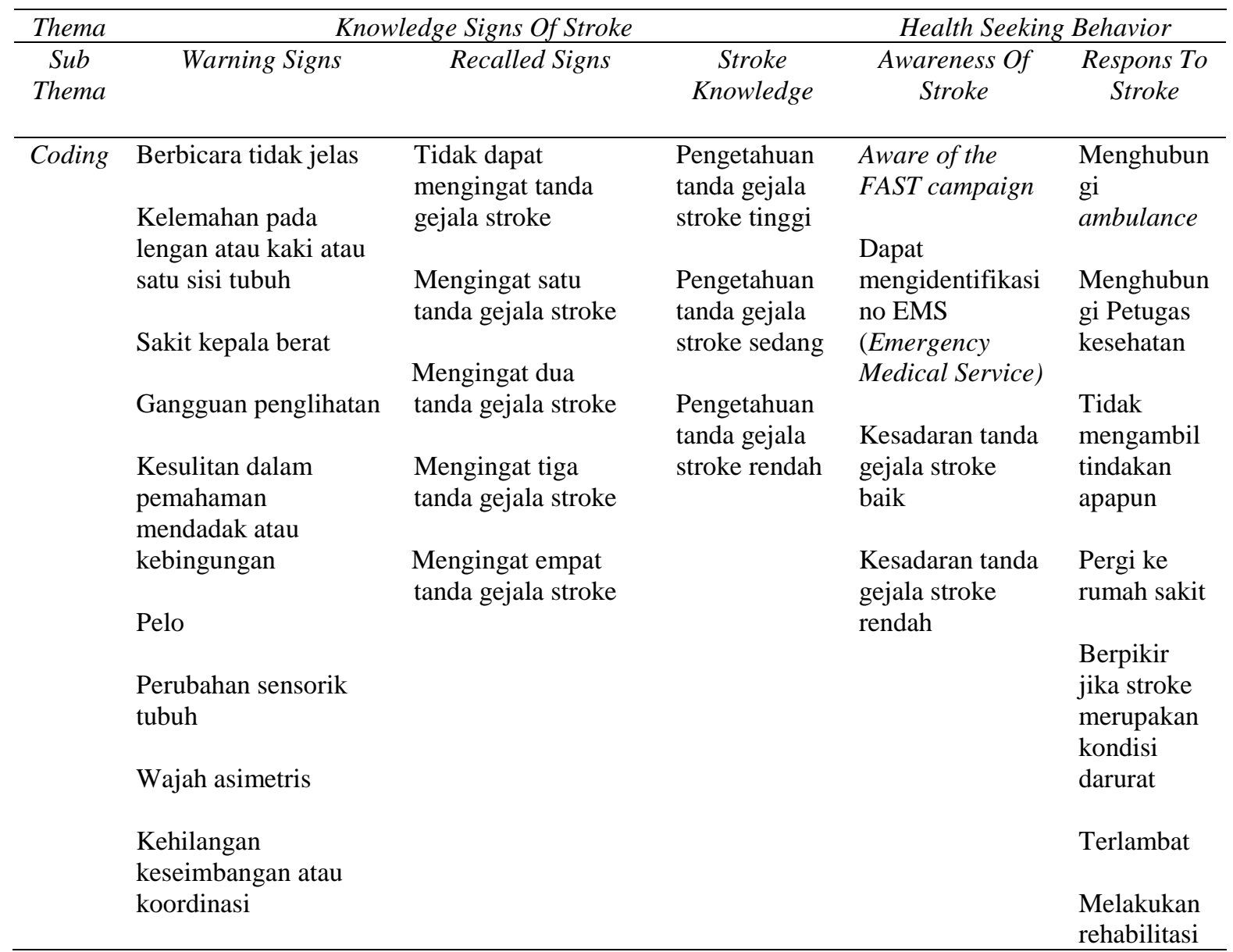

\section{Knowledge of Stroke}

Peneliti menganalisis hasil dari tema "Knowledge Of Stroke” berdasarkan sub-tema dan coding dari tujuh artikel yang didapat. Menurut Bietzk, E.,et all. (2012) pada penelitiannya yang menggunakan instrument kuesioner mengenai pengetahuan stroke dengan total sampel 356 individu risiko stroke dengan usia 18-80 tahun. Didapatkan hasil mengenai tanda gejala stroke yakni individu yang menjawab kesulitan berbicara 96,6\% (345), kelemahan pada lengan atau kaki 94,4\% (336), berasal bukan dari demam dan sesak nafas 64,0\% (228). Individu yang dapat menyebutkan kembali empat tanda gejala stroke $27,7 \%$, tiga tanda $17,3 \%$, dua tanda $13 \%$, dan satu tanda $9,5 \%$ dan tidak dapat menyebutkan satupun tanda 32,5\%. Hasil dari artikel tersebut menyimpulkan bahwa tingkat pengetahuan individu tersebut dikategorikan baik dengan rata-rata skor 11.8/15.

Hickey, A.,et all. (2012) dalam penelitiannya menunjukan individu yang dapat menjawab dengan benar tanda gejala stroke yakni kelemahan pada satu sisi tubuh 14,\%, sakit kepala 16,2\%, kesulitan berbicara 23,3\%, pusing 19,7\%, 8,3\% masalah penglihatan, 7,9\% kesulitan dalam pemahaman mendadak atau kebingungan. Pengetahuan individu dalam penelitian tersebut tergolong rendah karena hanya $31 \%$ individu yang dapat menyebutkan 
kembali dua tanda gejala stroke. Oleh karena itu penelitian yang dilakukan Hickey, A., et all. (2012) mengenai tingkat pengetahuan gejala stroke masih rendah.

Lakshmi, K., et all. (2014), dalam penelitiannya menunjukan individu yang menjadi responden dalam penelitian tersebut tingkat pengetahuan mengenai stroke masih rendah dimana didapatkan hasil dari 174 responden $63 \%$ dapat disimpulkan mereka dapat menjawab tanda dan gejala stroke yakni kesuliatan berbicara, kelemahan pada tungkai. Namun mereka tidak dapat mengingat kembali/menyebutkan kembali tanda gejala stroke.

Anuar, D, MK., et al. (2014), dalam penelitiannya yang memiliki jumlah sampel 112 individu dengan risiko stroke dengan instrument pertanyaan pengkajian pengetahuan tanda gejala stroke menunjukan hasil sebagai berikut. Cukup tingginya jumlah responden, mampu mengidentifikasi setidaknya satu peringatan tanda stroke. Hal yang paling umum diidentifikasi dari tanda gejala stroke yakni perubahan sensasi satu tungkai (57\%), diikuti oleh asimetri wajah $(41 \%)$ dan kelemahan pada lengan (32\%), lebih dari seperempat responden (27\%) tidak dapatmengidentifikasi satupun tanda gelaja stroke. Penelitian tersebut menyimpulkan bahwa tingkat pengetahuan tanda gejala stroke masuk dalam kategori rendah karena hanya $35 \%$ yang memiliki tingkat pengetahuan tanda gejala stroke yang memuaskan $(\mathrm{p}=0.04)$.

Hickey, A., et al. (2009), dalam penelitiannya yang menggunakan sampel 2033 individu dengan risiko stroke dan dilakukan ujian mengenai tanda gejala stroke pada komunitas orang dewasa. Hasil penelitian tersebut menunjukan bahwa tingkat pengetahuan responden masih rendah ( $\mathrm{p}<0.001)$, karena ketika ditunjukan list tanda gejala stroke hanya kesulitan bicara yang dapat dijawab oleh responden yakni sebesar 54\%, sedangkan kelemahan 38\%, tidak mengetahui tanda gejala stroke $13 \%$, pusing $44 \%$, sakit kepala $29 \%$, masalah penglihatan $20 \%$, sulit memahami $18 \%$.

Wahab, K. W., et al. (2008), dalam penelitiannya yang menggunakan 225 responden dengan menggunakan kuesioner didapatkan hasil tingkat pengetahuan terhadap tanda gejala stroke masih rendah. Didapatkan hasil bahwa hanya 55 individu yang dapat menjawab tanda gejala stroke yakni kelemahan pada satu sisi secara tiba-tiba, 30 individu menjawab kehilangan koordinasi, 27 individu pusing secara tiba-tiba, 17 individu menjawab kesulitan berbicara, 136 individu tidak mengetahui tanda gejala stroke. Begitu juga hasil yang dapat mengingat kembali tanda gejala stroke, hanya 10 individu yang dapat mengingat 3 tanda gejala, 20 individu yang dapat mengingat 2 gejala, 59 individu mengingat 1 tanda gejala, dan 136 individu tidak dapat mengingat kembali tanda gejala stroke.

Zulfa, R. (2012) dalam penelitiannya dengan menggunakan sampel 85 individu yang memiliki risiko stroke didapatkan hasil yakni pertanyaan kuesioner tetang gejala stroke sebanyak $76,5 \%$ dapat menyebutkan minimal satu gejala stroke dan yang paling banyak menyebutkan kelemahan sisi 56,4\%. Responden dengan pengetahuan mengenai tanda gejala awal stroke yang baik sebanyak 13 orang (15,3\%), Penelitian ini juga menunjukan bahwa ada hubungan antara individu yang memiliki tingkat risiko stroke sedang dan rendah dengan pengetahuan tentang tanda gejala stroke sedang dengan jumlah 65 responden dan individu yang memiliki faktor risiko stroke yang tinggi mempunyai 5,8 kali pengetahuan tentang stroke yang lebih baik.

Hasil dari analisis peneliti terkait dengan tema "Knowledge ff Stroke dapat disimpulkan bahwa individu yang mengalami risiko stroke kecenderungan memiliki tingkat pengetahuan yang rendah. Analisis yang dilakukan peneliti terhadap tujuh artikel yang di review sebagian besar memiliki kecenderungan tingkat pengetahuan yang rendah terhadap tanda gejala awal stroke. Hal ini dapat dilihat dari penelitian yang dilakukan oleh Lakshmi, K., et all. (2014), dalam penelitiannya didapatkan bahwa $41 \%$ menjawab tanda gejala stroke akibat dari demam, padahal menurut WHO (2016), demam bukan bagian dari tanda gejala stroke. Dari hal tersebut hampir setengah dari responden yang turut serta masih menyimpulkan bahwa demam merupakan tanda gejala awal dari stroke. 
Peneliti menemukan dari tujuh artikel yang dianalisis didapatkan masih banyak responden yang tidak dapat menyebutkan kembali tanda gejala awal stroke, seperti yang dilakukan Hickey, A.,et all. (2012) didapatkan hanya $31 \%$ individu yang dapat menyebutkan kembali dua tanda gejala stroke, dan pada penelitian yang dilakukan Wahab, K. W., et al. (2008), dari 225 responden sebanyak 136 individu tidak dapat mengingat kembali tanda gejala stroke, sehingga lebih dari $60 \%$ individu pada penelitian tersebut tidak dapat mengingat kembali tanda gejala awal stroke. Peneliti menyimpulkan bahwa re-call terhadap tanda gejala awal stroke masih rendah.

Arikunto (2010) mengatakan bahwa tingkat pengetahuan yang rendah dapat dilihat dari persentase yang didapatkan yakni $\leq 50 \%$, sedangkan untuk tingkat pengetahuan sedang 56$75 \%$, dan yang memiliki tingkat pengetahuan tinggi yakni 76-100\%. Hal ini dapat dilihat dari hasil-hasil yang didapatkan mengenai tingkat pengetahuan tanda gejala awal stroke masih dikatagorikan rendah karena rata-rata hasil yang didapatkan dari berbagai tanda gejala masih dibawah 50\%. Oleh karena itu peneliti menyimpulkan hasil analisis dari tujuh artikel yaitu tingkat pengetahuan tanda gejala awal stroke pada individu yang memiliki risiko stroke memiliki tingkat pengetahuan yang rendah.

\section{Health Seeking Behavior}

Deteksi dan identifikasi dini dilakukan sebagai upaya awal untuk seseorang kemudian dapat mengambil keputusan mencari bantuan kesehatan sesegera mungkin untuk mencegah terjadinya perburukan gejala stroke. Kesadaran dan respon cepat akan stroke khususnya pada individu dengan risiko stroke sangat memengaruhi bagaimana penanganannya. Penanganan pada pasien stroke maksimal 6 jam setelah mengalami onset namun prinsip yang harus diingat adalah semakin cepat, semakin minimal kerusakan sela otak yang terjadi (Wahjoepramono, 2010).

Penelitian yang dilakukan Bietzk, E.,et all. (2012) melaporkan bahwa sebanyak 64\% mengatakan mereka sadar terhadap FAST campaign karena sangat membantu mereka untuk meningkatkan pengetahuan mereka mengenai stroke beserta gejala yang ditimbulkan. Hasil penelitian Hickey, A.,et all. (2012) menunjukan bahwa 50,30\% individu ketika didiagnosa memiliki stroke atau mengalami beberapa tanda gejala stroke mereka akan menghubungi ambulance, sebanyak $21.18 \%$ akan menghubungi dokter, sebanyak 6,3\% menuju ke rumah sakit, dan sebanyak $28,7 \%$ tidak melakukan tindakan untuk menghubungi petugas kesehatan. Begitu juga dalam penelitian Lakshmi, K.,et all. (2014), sebanyak 77\% dari responden merasa stroke merupakan kondisi emergency dan mereka akan membawa pasien dengan stroke pergi ke rumah sakit segera, sebanyak 17\% menghubungi dokter, dan sebanyak $93 \%$ tidak mengetahui pengobatan dari stroke. Namun, mereka akan pergi ke rumah sakit untuk meminta bantuan petugas kesehatan. Anuar, D, MK., et all.(2014), dalam penelitiannya menjelaskan $18 \%$ responden dapat mengidentifikasi EMS (Emergency Medical Services) number, $11 \%$ dari mereka sadar akan kondisi emergency dari stroke, 58\% mengatakan bahwa rehabilitasi sangat penting untuk pengobatan stroke, namun hanya $35 \%$ responden yang memiliki kesadaran yang memuaskan akan stroke.

Berdasarkan tema "Health Seeking Behavior", peneliti menganalisis bagaimana perilaku individu yang memiliki risiko stroke terhadap kesadaran dan kemauan individu untuk sadar dan memutuskan untuk mencari bantuan kesehatan. Hasil yang didapatkan secara keseluruhan artikel mengatakan kesadaran akan gejala stroke atau mengenai stroke masih rendah. Hal ini dibuktikan dari beberapa penelitian yang telah dibahas sebelumnya. Wahab, K. W., et al. (2008) juga menyimpulkan bahwa kesadaran akan tanda gejala awal stroke masih rendah.

Kesadaran tanda gejala stroke didapatkan rendah karena individu tersebut memiliki tingkat pengetahuan yang masih tergolong rendah, namun kesadaran untuk mencari bantuan kesehatan dalam katagori baik. Hasil penelitian yang dilakukan Zulfa, R. (2012) menjelaskan 
bahwa 78,8\% responden setuju jika mengalami tanda gejala dari stroke, individu harus dibawa ke rumah sakit. Hal ini dapat disimpulkan bahwa kesadaran akan tanda gejala awl stroke yang dimiliki individu tidak memengaruhi mereka untuk tetap mencari bantuan kesehatan seperti menghubungi ambulance, dokter, dan pergi ke rumah sakit.

Peneliti telah membahas bagaimana tingkat pengetahuan individu terhadap tanda gejala awal stroke dan perilaku individu untuk mencari bantuan kesehatan. Dari hasil yang yang telah dianalisis bahwa tingkat pengetahuan masuk dalam kategori rendah, dan kesadaran individu akan tanda gejala awal stroke juga masuk dalam kategori rendah. Peneliti menemukan hasil dari artikel-artikel yang dianalisis mengungkapkan bahwa mereka akan mencari bantuan kesehatan seperti menghubungi ambulance, dokter, dan pergi ke rumah sakit, meskipun mereka memiliki tingkat pengetahuan dan kesadaran yang rendah terhadap tanda gejala awal stroke. Hal ini dapat dilihat dalam penelitian yang dilakukan oleh Anuar, D, MK., et all.(2014), Lakshmi, K., et all. (2014), Hickey, A., et all. (2012).

Hickey, A., et al. (2012) menemukan bahwa tidak ada hubungan antara pengetahuan tentang tanda gejala stroke dan keputusan untuk memanggil bantuan kesehatan. Tidak ada hubungan yang signifikan antara pengetahuan tentang tanda-tanda peringatan stroke dan kemungkinan untuk memanggil ambulans dalam hal dicurigai stroke. Begitu juga dalam penelitian Zulfa, R.(2012), mengungkapkan bahwa tidak ada hubungan antara tingkat pengetahuan individu dengan perilaku untuk mencari bantuan kesehatan.

Hasil kajian literatur ini menunjukkan bahwa tingkat pengetahuan dan kesadaran yang rendah terhadap tanda gejala stroke tidak ada kaitannya terhadap perilaku seseorang untuk menghubungi petugas kesehatan. Oleh karena itu, peneliti menyimpulkan tidak ada hubungan antara tingkat pengetahuan tanda gejala awal stroke terhadap keputusan mencari bantuan kesehatan pada individu dengan risiko stroke.

\section{SIMPULAN}

Kajian literatur ini dianalisis dari tujuh artikel yang diambil dari lima data base dengan menggunakan tujuh kata kunci yang saling berhubungan antara pengetahuan tanda gejala stroke dengan keputusan mencari bantuan kesehatan. Beberapa artikel melaporkan bahwa tingkat pengetahuan dan kesadaran individu terhadap tanda gejala awal stroke masih rendah. Namun, perilaku untuk sadar dalam mencari bantuan kesehatan termasuk dalam kategori baik. Peneliti menyimpulkan bahwa kesadaran terhadap tanda gejala stroke tidak memengaruhi perilaku seseorang untuk mencari bantuan kesehatan. Peneliti menyimpulkan bahwa tidak ada hubungan antara tingkat pengetahuan tanda gejala stroke dengan keputusan mencari bantuan kesehatan.

\section{SARAN}

Pengetahuan dan kesadaran terhadap tanda gejala stroke masih tergolong rendah. Kurangnya kesadaran masyarakat tentang stroke dan tanda gejala stroke harus ditangani sebagai salah satu kontribusi penting untuk mengurangi mortalitas dan morbiditas dari stroke. Meningkatkan kesadaran terhadap tanda gejala awal stroke dapat dilakukan dengan cara memberikan edukasi kesehatan tentang tanda gejala stroke, faktor risiko stroke, dan akibat yang didapatkan jika seseorang terlambat untuk mencari bantuan kesehatan.

\section{DAFTAR PUSTAKA}

Arikunto. (2010). Prosedur Penelitian: Suatu Pendekatan Praktek. Jakarta: Rineka Cipta.

Aromataris, E., \& Riitano, D. (2014). Systematic Reviews. AJN, American Journal of Nursing, 114(5), 49-56. doi:10.1097/01.naj.0000446779.99522.f6 
Aveyard, H. (2014). Doing a literature review in health and social care: A practical guide. Ed.3. Maidenhead: McGraw-Hill/Open University Press.

Departement Kesehatan RI. (2008). Riset Kesehatan Dasar 2007. Jakarta

Wahjoepramono (2010). 171 Tanya Jawab Tentang Stroke. Ed.1. Hal. 23-24. ISBN 978-97922-545-6. PT Gramedia Pustaka Utama: Jakarta.

European Society Of Cardiology. (2012). Atrial Fibrillation Is A Modifiable Risk Factor For Stroke. Italy. Diunduh Pada Hari, Selasa, 12 April 2016. Retrieved from

http://www.escardio.org/The-ESC/Press-Office/Press-releases/Last-5-years/Atrialfibrillation-is-a-modifiable-risk-factor-for-stroke

Lakshmi K, Viswanath K, Ze CE, Sam Marconi D, David SN, Isaac R. (2014). Stroke care challenges in rural India: Awareness of causes, preventive measures and treatment options of stroke among the rural communities. IndJ Comm Health 2014;26(4):350 356.

Moule, P. \& Goodman, M. (2009). Nursing research. An introduction. Sage Publications Ltd, United Kingdom. 184, 191, 261.

Wager, E. \& Wiffen, J, P. (2011). Journal Evidence-Based Medicine. Ethical Issues in Preparing and Publishing Systematic Reviews. Doi 10.1111/j.1756-5391.2011.01122.x. ISSN 1756-5391.

World Health Organization. (2016). Stroke, Cerebrovascular Accident. Diunduh Pada Hari, Sabtu, 20 Febuari 2016 dari http://www.who.int/topics/cerebrovascular_accident/en/

Zulfa, R. (2012). Hubungan Tingkat Faktor Risiko Dengan Pengetahuan Stroke Pada Kelompok Usia Di Atas 35 Tahun Di RW 09 Kelurahan Cirendeu Kecamatan Ciputat Timur Tahun 2012. Fakultas Kedokteran dan Ilmu Kesehatan Universitas Islam Negeri Syarif Hidayahtullah: Jakarta. 